\title{
A Girl Activist Inventory
}

\author{
Claudia Mitchell
}

\section{$\cos 80$}

In March 2019, I had the pleasure of giving a talk at Peter Green College at the University of British Columbia that I called "The Politics and Possibilities of Girl-led and Youth-led Arts-based Activism to Address Gender Violence." I wanted to highlight in particular the activist work of numerous groups of Indigenous girls and young women in a current project ${ }^{1}$ and the youth AIDS activist work of the Fire and Hope project in South Africa ${ }^{2}$ but I also wanted to place this work in the context of girls' activism and youth activism more broadly. To do this I started out with a short activity called "Know your Girl Activist" during which I showed PowerPoint photos of some key girl and young women activists of the last few years, and asked the audience if they could identify them. The activists included two Nobel Prize Peace Prize winners, Malala Yousafzai (2014) and Nadia Murad (2018) along with Autumn Pelletier, the young Indigenous woman from Northern Ontario, Canada, well known for her work on water activism, and, of course, Greta Thunberg, now a household name but then, in 2019, already well known for her work on climate change activism. To my surprise only some of these activists were recognized, so, during the $\mathrm{Q}$ and A session, when I was asked if there is a history of girls as activists I could see that this question indicated clearly the urgent need for this special issue of Girlhood Studies which was only just in process then. Now, thanks to the dedication of the two guest editors of this special issue, Catherine Vanner and Anuradha Dugal and the wide range of superb contributors, I can point confidently to girls' activism as a burgeoning area of study in contemporary feminism rooted in feminist history.

Then, just as this special issue was about to go to press The Girl Museum $^{3}$ launched its new online Young Suffrage Exhibition. What is most fascinating about the exhibition is its recognition of the critical place of girls' activism as a social movement in and of itself, but also its contribution to social change more broadly. 


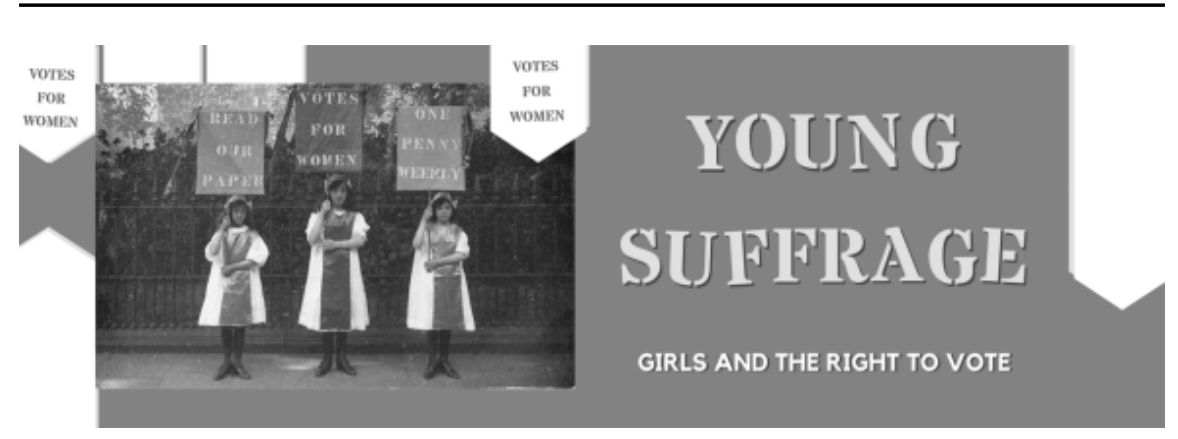

Banner for Young Suffrage exhibition, Girl Museum, 2020. Original image, "Suffragette poster parade," H. Searjeant, 1911, provided by Museum of London. Poster parade of young suffragettes advertising Votes for Women, the weekly newspaper of the Women's Social and Political Union. The young Suffragettes were taking part in the Coronation Procession of 1911 as part of the Votes for Women newspaper contingent.

As for my "Know your Girl Activist" activity, the best thing about starting an inventory is that you can keeping adding to it. I used the PowerPoint presentation when I met with a group of girls and young women with disabilities in Vietnam ${ }^{4}$ who are themselves doing important activist work on inclusion, only this time I included a picture of Zee Ncgobo, the young transgender woman activist, then 19 years of age, from Loskop in rural South Africa who was a key-note speaker at the South African AIDS conference in Durban in 2019. My next presentation will include an image from the work with the girl groups in Vietnam. The activist agenda expands along with the inventory.

\section{Notes}

1. The Principal Investigators of Networks for Change and Well-being Girl-led 'From the Ground up' Policy to Address Sexual Violence in Canada and South Africa (2013-2021) are Claudia Mitchell and Relebohile Moletsane.

2. The Principal Investigator of We Grew as We Grew: Longitudinal Perspectives on Youth Activism, Visual Methodologies, and HIV Prevention (2017-2019) was Shannon Walsh.

3. https://www.girlmuseum.org/

4. The Principal Investigator of Transforming Knowledge and Activism for Inclusion through Engaging Girls and Women with Disabilities in Vietnam in Participatory Research (2016-2020) is Xuan Thuy Nguyen. 